Golden Gate University School of Law GGU Law Digital Commons

1993

\title{
The New New International Economic Order: Private International Law
}

Helen E. Hartnell

Golden Gate University School of Law, hhartnell@gmail.com

Follow this and additional works at: http://digitalcommons.law.ggu.edu/pubs

Part of the International Law Commons

Recommended Citation

87 Am. Society Int'l. L. Proc. 462 (1993)

This Article is brought to you for free and open access by the Faculty Scholarship at GGU Law Digital Commons. It has been accepted for inclusion in Publications by an authorized administrator of GGU Law Digital Commons. For more information, please contact jischer@ggu.edu. 
on such issues as national treatment, dispute settlement and abolition of performance requirements, the United States itself and other developed countries had begun to rethink their own principles. We see, in the European Community and the United States, hints of a resurgent economic nationalism, for example, through the beginnings of legislation that would draw distinctions between how companies are treated based on the nationality of the ownership of the capital stock. So, while the United States and other developed countries have been successful in moving the developing world more toward their position, I think international lawyers and scholars need to be alert to whether or not the United States is perhaps moving in the other direction.

We have had an interesting four or five years in the development of international economic law. The developments are bound to continue, as a number of the Asian nations become more active in international affairs, as the global community begins to feel the full impact of the dissolution of the former Soviet Union, and as we begin to look to Latin America for leadership, as it works through many of these issues.

\section{The New New International Economic Order: Private International LaW}

\section{By Helen Elizabeth Hartnell*}

During this decade of international law, we are challenged to reflect on the role of law in shaping international relations, and then to set our course for the coming years. Today, we are called upon to consider the changes since December 1974, when a resolution incorporating the Charter of Economic Rights and Duties of States was adopted by the UN General Assembly. ${ }^{1}$ That controversial Charter embodied a starkly bipolar view of the world that divided North from South, developed from developing, and posited that the tension between these poles, "if not properly checked, would [counteract the tendencies toward integration and interdependence and] lead to the disintegration of the world community."2

One of our crosscutting themes this week is "Our Changing Sense of Community." We are told that, since the end of the Cold War, we no longer live in a bipolar world. It is true that the end of the East-West conflict has removed one set of divisions. ${ }^{3}$ Yet, we are still spread along various spectra that color our perceptions. The gap remains between developed and developing, between investor and host, even while the wealthiest countries are beset with worries and the strongest economies stumble. It is an unfortunate irony that though our circumstances are de facto closer than ever in these hard times, we tend to focus on our

\footnotetext{
* Faculty of Law, Central European University, Budapest; Civic Education Project Instructor, Eötvös Loránd (ELTE) University.

' Report of the Second Committee, UN Doc.A/9946, 28 (Dec. 9, 1974); UN Doc.A/Res/3281 (XXIX) (Jan. 15, 1975); reprinted in 14 ILM 251. The roll-call vote was 120 in favor, 6 opposed (Belgium, Denmark, the Federal Republic of Germany, Luxembourg, the United Kingdom, and the United States), and 10 abstentions (Austria, Canada, France, Ireland, Israel, Italy, Japan, the Netherlands, Norway, and Spain). (1975).

${ }^{2}$ Speech of Emilio O. Rabasa, Secretary of Foreign Relations of Mexico, 68 ASIL Proc. 302

${ }^{3}$ In one sense, then, the Central/East European countries are now free to join the rest of the developing world, and to "[comprehend] the principles of the self-reliance of the individual which implies misery, homelessness or starvation as penalty for failure." Czeslaw Milosz, Central European Attitudes, 5 Cross Currents 101, 104 (1986). See also K. J. Zaleska, Local Cultural Responses to Multinationals, in 1 Nationalism Notes 23 (November 1992).
} 
differences rather than our similarities in the struggle to survive. This natural tendency to cling to differences also serves as a means to preserve identity in the face of globalization, particularly in those countries where not everyone is able successfully to enjoy the material benefits and assimilate the ideological values of the new global high culture. ${ }^{4}$ So while we surely must embrace this new opportunity to converge with countries now emerging from decades of isolation, the revival of ardent nationalism reminds us not to congratulate ourselves too heartily.

The failed Charter of Economic Rights and Duties of States, like the failed Soviet Union, was built by "levellers." 5 Their failure is rooted in the inevitability of diversity. Today's scrambling toward political, economic and legal integration in the eastern and western hemispheres might be seen to stem from fear of the consequences of too much difference, or from a recognition that cooperation can erase destructive differences. In any case, integration always has its limits; something is always held back. That "something" held back-the domaine réservé-is another of our crosscutting themes this week.

The domaine réservé, a key feature of the international legal system, denotes the point at which differences begin to overshadow common values and interests. One need not look far to discover attempts to define the boundary between "us" and "them," between particular and universal, and between national/state autonomy/sovereignty and globalization. This phenomenon may be observed in two familiar contexts. First, a pervasive tension exists in countries consisting of federations of states (such as the United States) and other confederations (such as the European Community) concerning the extent of legislative (that is, prescriptive) jurisdiction possessed by the central authorities. The meaning of "federalism" in the United States has yet to be settled once and for all, and the debates in the EC surrounding the Maastricht Treaty on European Union and the doctrine of subsidiarity $^{6}$ are unlikely to subside soon. Secondly, even states that have by treaty agreed to submit to certain common rules generally leave an avenue of escape from the international regime they have helped to create. Most often, such exceptions are based on vague notions of "public policy" or related doctrines. In either case, the concept of domaine réservé implies an identity that needs to be preserved by a process of differentiation.

Not only are differences inevitable; they are desirable, up to a point. Indeed, the notion of competitive advantage is the foundation of the international trading regime. The famous example from the experience of the EC simply invokes "bread, beer and cheese" as proof of the desirability of preserving local differences. Diversity may also be desirable within a federal system, if one believes that the states should "serve as laboratories for social and economic experiment," and must therefore be "free to engage in any activity that their citizens choose for the common weal, no matter how unorthodox or unnecessary anyone else . . . deems state involvement to be." These few examples are only meant to suggest, but not to exhaust the variety of political, cultural and economic factors that are implicated.

\footnotetext{
4 See Gabriela Apostol, 1 NAtionalism Notes 18, 19: (Globalization can be viewed as "penetration of capitalist market forces . . . or in terms of cultural homogenization through the world-wide spreading of certain consumer goods and values").

"See Czeslaw Milosz, citing Stanislaw Witkiewicz, supra note 4, at 105-06.

"See, e.g.. Nicholas Emiliou, Subsidiarity: An Effective Barrier Against "the Enterprises of Ambition"? 17 Eur. L. REv. 383 (1992).

${ }^{7}$ Garcia v. San Antonio Metro. Transit Authority, 469 U.S. 528, 546 (1985) (Blackmun, J.) (citing New State Ice Co. v. Liebmann, 285 U.S. 262, 311 (1932) (Brandeis, J., dissenting)).
} 
According to Carlos Fuentes, the Mexican author, the "universal question of the coming century" is, "How do we deal with the "Other'?"8 This is as true in law as in other fields. It would be preaching to the converted to argue here that some of the problems we face call increasingly for regional or global solutions. Yet our enthusiasm for international cooperation must be tempered by respect for the integrity of that which cannot be compromised. Our task, then, is to enunciate criteria for determining when and what sort of common rules are desirable, and conversely, to consider how to define those areas in which, and the methods by which, differences must be preserved. The extent to which "national governments should ... be required to relinquish their ability to influence events or institutions in a way that suits national culture" has aptly been called the "true international federalism issue."

\section{Private International Law}

The domain of international law has expanded to encompass matters traditionally thought to be within domestic jurisdiction via private international law (PIL) conventions and related phenomena. I wish to refer broadly to the unification and harmonization of legal rules and procedures governing the relations between private parties. This is by no means a new phenomenon; it is not only going strong, but growing stronger. My goal today is not to survey current developments in this field so much as to reflect upon some pervasive themes.

The nature of PIL work is varied and depends partly upon the character of the institution engaged in unifying or harmonizing the law. At the low end of the spectrum are standard definitions ${ }^{10}$ and contracts ${ }^{11}$ for use in international trade. Such texts are often said to represent mere codifications of mercantile practice. In any event, standard terms or contracts do not have the force of law per se; they govern a transaction only if the parties have chosen to incorporate them into their agreement. The high end of the spectrum is inhabited by PIL conventions that set forth legal rules to govern choice of law, procedural or substantive issues within their scope. Let us consider these issues in turn.

Efforts to unify choice of law norms enjoy a long history, but only modest success. Most efforts in this field have been undertaken by the Hague Conference on Private International Law, which is celebrating its centennial anniversary in 1993. Neither the Hague Conference Convention on the Law Applicable to Contracts for the International Sale of Goods (1985), nor those on the Law Applicable to Succession to the Estates of Deceased Persons and on the Law Applicable to Trusts and on their Recognition, have been widely adopted, although the latter are being considered for ratification in the United States. And despite the lack of enthusiasm usually generated within the United States by conventions of this kind, the Organization of American States (OAS) proposes to conclude a convention containing choice-of-law rules for certain contracts at its next intergovernmental PIL conference (CIDIP-V) in 1994. Within the European Community, the Rome Convention on the Law Applicable to Contractual Obligations provides the framework for analyzing all contractual choice-of-law questions that come before the courts of EC member states.

Efforts to unify procedural and substantive rules have been more fruitful on

8254 Nation 410 (1992).

9 John H. Jackson \& William J. Davey, Legal Problems of International Economic Rela. TIONS 1242 (2d ed. 1986).

${ }^{10}$ E.g., the inCOTERMS prepared by the International Chamber of Commerce.

${ }^{11}$ E.g., those prepared by the Economic Commission for Europe. 
the whole than efforts to unify choice-of-law rules. Notable examples in the area of procedure include the Hague Conference Conventions on the Service Abroad of Judicial and Extrajudicial Documents in Civil or Commercial Matters and on the Taking of Evidence Abroad in Civil and Commercial Matters. The OAS is also active in the procedural field. ${ }^{12}$ Most civil litigation in Western Europe is covered by the 1968 Brussels Convention on Jurisdiction and the Recognition of Judgments in Civil and Commercial Matters and the 1988 Lugano Convention that extended the framework established for EC member states to the countries of the European Free Trade Area (EFTA). And now the Hague Conference, prompted by the United States, is considering whether to prepare a jurisdiction and judgments convention for worldwide adoption.

The tireless drive to increase predictability and remove impediments to international trade by way of unifying substantive norms received some impetus from the successful conclusion and wide adoption of the Convention on Contracts for the International Sale of Goods (CISG) prepared by the UN Commission on International Trade Law (UNCITRAL). ${ }^{13}$ For example, conventions providing uniform norms to govern international factoring and financial leasing transactions were prepared by the International Institute for the Unification of Private Law (UNIDROIT) and are being considered for ratification in the United States and elsewhere. The UNCITRAL Conventions on International Bills of Exchange and International Promissory Notes, on the Limitation Period in the International Sale of Goods, and on the Liability of Operators of Transport Terminals are also being considered for ratification. And, within the European Community, efforts to unify some areas of substantive law of the member states via regulations persist. ${ }^{14}$

Between these poles, various alternative PIL devices proliferate. Where once the pendulum swung away from voluntary toward compulsory measures (which might or might not yield to party autonomy), and away from unification of choiceof-law rules toward more comprehensive unification of substantive norms, we are now witnessing a course correction. It is ironic that UNCITRAL, which has achieved the greatest success so far in terms of formal unification of substantive law, has been the one to shift its focus away from binding normative systems toward "soft law," such as nonbinding legal guides (for example, on contracts for the construction of industrial works and on countertrade) and model laws (for example, on bank guarantees and standby letters of credit, on procurement, and on international credit transfers). UNIDROIT, on the other hand, continues its eclectic approach to PIL work, balancing efforts to prepare conventions on substantive issues (for example, protection of cultural property and security interests in mobile equipment) and conflict of law issues (for example, law applicable to international credit transfers), with efforts to complete drafting nonbinding General Principles for International Commercial Contracts. In contrast, the work of the Hague Conference and the OAS continues, in the traditional vein, to focus on binding conventions that regulate assorted procedural and choice-of-law issues.

The retreat from formal unification of substantive law is most apparent within

\footnotetext{
12 For example, it has concluded Inter-American Conventions on International Commercial Arbitratıon, on Letters Rogatory, on Taking Evidence Abroad, and on the International Return of Minors.

${ }^{13}$ One reason for the success of the CISG vis-à-vis earlier efforts to promote international rules for the sale of goods is that UNCITRAL is more inclusive than the traditional Eurocentric approaches toward uniform substantive law.

${ }^{14}$ See, e.g. . Amended Proposal for a regulation on the Statute for a European company, 1991 O.J. (C 176), at 9 .
} 
the EC, and changing European attitudes are spilling over from the regional cup into the global bowl. Yet, this shift indicates, not that the "obstinate apostle[s] of the unified market"Is are on the run, but rather that they have altered their tactics. The European Court's 1979 Cassis de Dijon decision ${ }^{16}$ establishing the principle of mutual recognition later became the linchpin of the Commission's "new approach" to harmonization initiated by its 1985 White Paper on Completing the Internal Market. ${ }^{17}$ The combined emphasis on "home country control" and mutual recognition "implicitly recognizes competition between legal orders as a substitute for harmonization." 18

A further aspect of the EC's modern approach to integration is a stated preference for harmonization (via directives) over unification (via regulations). ${ }^{19}$ The term "harmonization" is used here to refer to measures that fall short of normative unification, measures that instead constitute an approximation (rapprochement or Angleichung) of rules or a coordination of policies. ${ }^{20}$ This movement is calculated to "allow greater latitude to participating States in the articulation of norms, while still ensuring uniformity in the results of their application" and may be referred to as "the unification of objectives." 21 Implicit in harmonization is a recognition of the necessity and even the desirability of accommodating differences. ${ }^{22}$ Such harmonization is being carried out, not only within the framework of the EC itself, pursuant to Articles 100,100A and 235 of the Treaty of Rome; it is also spreading de jure to certain EFTA countries (pursuant to the European Economic Area Agreement). In addition, the reach of EC harmonizing directives is extending into Central and Eastern Europe, pursuant to the EC's network of association and cooperation agreements. For example, Article 69 of the 1991 Europe Agreement between Hungary and the EC requires Hungary to approximate its legislation to that of the EC "as far as possible" in all major areas of economic law. ${ }^{23}$

${ }^{15}$ See Julian Currall, Some Aspects of the Relation between Articles 30-36 and Article 100 of the EEC Treaty, with a Closer Look at Optional Harmonisation, 4 Y.B. EuR. L. 169, 179 (1985).

${ }^{16} R E W E$, case 120/79, [1979] ECR 649.

${ }^{17}$ COM 310 final (14 June 1985).

${ }^{18}$ See Norbert Reich, Competition Between Legal Orders: A New Paradigm of EC Law?, 29 CoM. MON MKT. L. REv. 861 (1992).

${ }^{19}$ See Daniel Vignes, The Harmonisation of National Legislation and the EEC, 15 EUR. L. REv. 358 (1990). See also Martin Boodman, The Myth Of Harmonization Of Laws, 39 AM. J. Comp. L. 699,718 (1991). ("The arguments in favor of harmonization of laws generally . . . based on certainty in the law . . . raise serious issues of legal and political theory regarding hermeneutics, legal reasoning and the role of precedent, as well as the role of formal systems of law in states and society. These issues are not addressed in any detail in the literature regarding harmonization of laws and . . . are unresolved.").

${ }^{20}$ H. P. Glenn, Harmonization of Private Law Rules Between Civil and Common Law Jurisdictions: General Report, XIIIth INTERnational Congress of Comparative Law 1, 3 (Montreal, 1990). Harmonization may be formal (i.e., achieved via bilateral or multilateral institutional efforts) or informal.

${ }^{21}$ Glenn, supra note 20, at 4. See also H. Duintjer Tebbens, Private International Law and the Single European Market: Coexistence or Cohabitation?, in UNIVERSITY OF AMSTERDAM, FORTY YEARS ON: The Evolution OF Postwar PIL in EuROPE 49 (1990) (observing the expanding range of private law matters covered by harmonizing directives in recent years).

${ }^{22}$ Compare Glenn, supra note 20, at 2 ("Harmonization, if it is said to exist, must . . . accommodate and encadre disagreement.") with Boodman, supra note 19, at 718 (suggestion that there must be a market for laws in order to justify harmonization).

${ }^{23} E . g$., customs law, company law, banking law, company accounts and taxes, intellectual property, protection of workers at the workplace, financial services, rules on competition, protection of health and life of humans, animals and plants, food legislation, consumer protection (including product liability), indirect taxation, technical rules and standards, transport and the environment. 
Although harmonization is largely a European phenomenon, ${ }^{24}$ it ought nevertheless to be understood in the context of the overall reevaluation of the usefulness of traditional PIL devices. The grounds for the retreat from formal unification of substantive norms are many, not least of which is the realization that European "economic integration need not be accompanied by a single legal space, not even in those parts of the law that have a direct bearing upon the free movement of persons, goods, services and capital within the Community," since "a unified market can perfectly co-exist with a plurality of legal systems," 25 such as in the United States. Complete uniformity, in other words, is unnecessary.

In a broader sense, the "shift away from standardization results from a realization that true uniformity of laws among sovereign jurisdictions is a doubtful, if not impossible, goal." ${ }^{26}$ The retreat thus also reflects acceptance of both the political untenability of uniformity and the inevitability of the conflict of laws. The existence of binding uniform substantive norms may reduce, but cannot eliminate, the occasional need to resort to conflict-of-laws analysis, unless the legal system created is an autonomous one. Code-minded civil law scholars have made recent attempts in this direction, for example by urging that gaps in uniform substantive laws should be filled by resort to "general principles" rather than to the law of a national jurisdiction. ${ }^{27}$ On the whole, however, these efforts have failed, and we are left with even more complex conflict-of-laws problems than we had before, owing both to the nature of the questions that arise under a PIL convention and the quantity thereof that result from the proliferation of fragmentary enactments. ${ }^{28}$

A crucial factor in the analysis of whether to pursue the conclusion of binding uniform substantive norms is their value per se. Trenchant criticism abounds. First, a convention that lacks a mechanism to facilitate ongoing revision in order to adjust to changing circumstances would soon become a "fossil." 29 Secondly, the compromises inevitable during the consensus-seeking process may tend to unify norms at the level of the "lowest common denominator." Thirdly, uniform norms might be viewed as grey flannel products of the abstract rationalist tradition that ignore the "political, economic, historical and cultural context in which people live, $" 30$ or that "ignore governance norms which underlie seemingly private areas of the law." 31

Despite all of these potential shortcomings, I believe that the process of substantive unification (and harmonization) should continue. I do not mean to exalt the

\footnotetext{
${ }^{24}$ For a Canadian example, see Boodman, supra note 19.

25 Tebbens, supra note 21 , at 62.

${ }^{20}$ Boodman, supra note 19 , at 708 .

${ }^{27}$ This feature marks a significant difference between the 1964 Uniform Law for International Sales and the CISG (Article 7(2)) provides that "[q]uestions concerning matters governed by this Convention which are not expressly settled in it are to be settled in conformity with the general principles on which it is based or, in the absence of such principles, in conformity with the law applicable by virtue of the rules of private international law.").

${ }^{28}$ Hein Kotz, Rechtsvereinheitlichung: Nutzen, Methoden, Ziele, 50 RABELsZ 1 (1986) (describing the morass of rules as a "Hydra").

${ }^{29}$ Arthur Rosett, Critical Reflections on the UN Convention on Contracts for the International Sale of Goods, 45 OHio St. L. J. 265 (1984). See also Peter Behrens, Voraussetzungen und Grenzen der Rechtsfortbildung durch Rechtsvereinheitlichung, 50 RaBELSZ 19 (1986).

${ }^{30}$ Hilary Charlesworth, Christine Chinkin \& Shelley Wright, Feminist Approaches to International Lan', 85 AJIL 613 (1991).

${ }^{31}$ Project of Spencer W. Waller \& Joel Reidenberg, discussed in ASIL International Economic Law Interest Group Newsletter, Fall 1992, at 3.
} 
universality of principles of law. I do, however, believe that substantial common ground exists, and that it behooves us to search for these similarities, especially at such a time as this, when the temptation to colonize is great. In this way, we develop a common language, and build a foundation upon which later cooperation can be based. We counteract, or at least minimize, the polarization that divides us. And let it not be forgotten that unification (or harmonization) can be a device to increase rather than reduce the level of protection afforded in a particular context. $^{32}$ Viewed only in this light, uniformity sounds pretty harmless.

PIL devices to unify or harmonize substantive law can serve useful purposes in international trade, provided that their limitations are known and properly respected. The timeworn arguments cited in favor of efforts to achieve unification still carry some weight: to facilitate trade by removing impediments; to promote fairness by providing a modern, streamlined, neutral set of rules that parties can choose; and to facilitate the process of negotiation and alleviate the complexity of transnational dispute resolution by ensuring a higher degree of predictability. Indeed, some of these same justifications are being heard again in connection with the EC's incremental movement toward a common civil code of obligations for matters affecting economic life. Yet we have come a long way from the conviction that unification of law represents "the most important contribution which lawyers can make in the field of private law to the creation of a more harmonious and fraternal world.",33

The modern skepticism of the value of PIL conventions is healthy and should be channeled into improving the focus and functioning of the process. The focus should be on identifying truly problematic issues, particularly those that lie beyond the realm of parties' contractual autonomy. ${ }^{34}$ Despite the traditional reluctance to search for common ground in areas where "mandatory" or "imperative" local law is implicated, history is full of examples of creeping consensus in previously taboo areas. Nations have increasingly recognized that the needs of international commerce can outweigh their traditional concerns over public policy, and have worked toward unification in areas-such as formation of contract, prescription and property law-that were once viewed as too complex or controversial to lend themselves to unification. Who would have predicted, twenty years ago, the EC's current movement toward international standards for the protection of consumers? At the very least, we need to reexamine our traditional anxiety in areas where an international standard would further serve goals.

Lest the process be hobbled by its limitations, we need also to pay closer attention to the functioning of PIL conventions. The most intractable problems concern

\footnotetext{
${ }^{32}$ See, e.g., Article 100A (3) of the EEC Treaty, which provides that the Commission shall take as a base a "high level of protection" in the approximation of laws concerning health and safety (including consumer and environmental protection). Article $100 \mathrm{~A}$ (4) adds that EC member states maintaining an even more protective standard than the "high" level do not have to take a step down. See also CISG Article 14(1), (providing that an offer is too indefinite unless it "expressly or implicitly fixes or makes provision for determining the . . price"). This provision appears to raise the prohibition against open-price terms, found in the laws of some countries, to the level of an international norm.

${ }^{33}$ See André Tunc's commentary on the 1964 Hague Conventions on International Sale of Goods and the Formation of the Contract of Sale in Diplomatic Conference on the Unification of LaW Governing the International Sale of Goods (Records), The Hague 355 (1966).

${ }^{34}$ Ernst Rabel, Observations on the Utility of Unifying [the] Law of Sale from the Standpoint of the Needs of International Commerce (1929), in LEAGUE OF NATIONS: DRAFT OF AN INTERNATIONAL Law of THE SaLE of Goods 123, 128, 131 (1935).
} 
the nexus between the international uniform law and the various domestic laws it supplements or supplants. Since most PIL conventions are of limited scope, there is a point at which autonomous interpretation of its terms-necessary to achieve the desired uniform application-must yield to the conflict of laws. Scholars wrangle over how to ascertain this point. The validity exception to the CISG provides an apt example. ${ }^{35}$ Some would blur the interface by requiring autonomous, that is, uniform interpretation of the meaning of validity, based on a comparative law analysis inspired by the work of Rabel, while others argue that the power to define the parameters of scope provisions such as Article 4(a) CISG-which by their nature delimit the area of local sovereignty to be preserved-must lie with the local jurisdiction. In my view, the integrity of the unification process requires scrupulous respect for provisions, such as Article 4(a) CISG, designed to preserve the applicability of some local rules rooted in public policy. Nevertheless, a tribunal called upon to decide whether a particular contractual issue is one of validity that is governed by domestic law rather than the uniform rules of the CISG should exercise full caution. ${ }^{36}$

Further attention should be paid, in the process of unifying (and harmonizing) substantive law, to providing adequate conflict of laws provisions. Current debate within the EC illustrates the problems of overlapping and ill-fitting sets of rules and suggests that completion of the internal market is likely to enhance rather than diminish the role of conflict of laws, since "certain divergencies in national law are allowed to remain and even become greater in areas where the Member States have retained the power to determine their own level of legal protection.",37 This suggests that "where a substantive unification is not fully achieved, a common approach to the problem of how to allocate legal situations having connections with several units composing the market" becomes a prerequisite to equal competition throughout the internal market. ${ }^{38}$ There is a strong call within the EC for converging, if not identical, conflict rules. While a detailed discussion of these proposals is beyond the scope of this paper, it bears mention that some EC enactments contain choice-of-law rules that range from straightforward ${ }^{39}$ to detailed and highly complex, ${ }^{40}$ while others contain practically no such provisions. ${ }^{41}$ Both within and beyond the horizons of the $\mathrm{EC}$, it is imperative that unifying or harmo-

\footnotetext{
35 The case law of the European Court of Justice under the Brussels Convention also wrestles with this issue on a case-by-case basis. See Industrie Tessili Italiana Como v. Dunlop AG, 1 C.M.L.R. 26, 51-52 (1977): "The question therefore arises whether these words and concepts must be regarded as having their own independent meaning and as being thus common to all the member-States or as referring to substantive rules of the law applicable in each case under the rules of conflict of laws of the court before which the matter is first brought."

${ }^{36}$ This analysis is developed in Helen Hartnell, Rousing the Sleeping Dog: The Validity Exception to the Convention on Contracts for the International Sale of Goods, 18 YALE J. INT'L L. 1, 5 (1993).

${ }^{37}$ Tebbens, supra note 21 , at 51-52.

${ }^{38} I d$. at $67-68$.

${ }^{39}$ E.g. . Regulation No. 2137/85 creating the European Economic Interest Group, 1985 O.J. (L 199) at 1 (Article $2(1))$.

${ }^{4}$ E.g., Directive $88 / 357$ of 22 June 1988 on non-life insurance, 1988 O.J. (L 172) at 1 (renvoi to each member state's choice-of-law rules to determine the permissible extent of party autonomy and the impact of mandatory rules of certain connected laws other than the law designated by the uniform rules).

"Tebbens, supra note 21 , at 52 (noting that some recent directives "do not contain scope rules defining their own international applicability, nor do they indicate, when referring certain issues to 'national law,' how that law is to be selected").
} 
nizing enactments respect the already existing framework of internationally applicable choice-of-law rules. ${ }^{42}$

Finally, we need to acknowledge that the concept of public policy is an evolving one, in private as well as in public international law (jus cogens). "Public policy" is traditionally resorted to "on the basis of central and fundamental legal principles, values or interests of the State involved, to ward off the results of application of foreign law." 43 Yet, in the public international law arena, the notion of supranational fundamental rights or principles is steadily gaining ground. ${ }^{44}$ This trend is also well established in the jurisprudence of the European Court of Justice. ${ }^{45}$ It is ironic that the doctrine of ordre public can simultaneously serve the goals of both universalism and particularism. Already within the EC, there is a growing recognition that the concept of ordre public is no longer limited to national but must also accommodate the "ordre public communautaire." 46 Indeed, many scholars expect that the European Court will "review the way in which national courts make use of the public policy exception" under the Brussels Convention, ${ }^{47}$ while others would deny this competence to the European Court. According to Jessurun d'Oliveira, "[p]ublic policy is an autonomous concept, which may be interpreted independently from the insights of national judges by the European Court." 48 These developments suggest that a similar evolution may gradually occur within the broader framework of other regional or global PIL efforts, although certainly not to the same extent as is likely to be achieved within the EC. We might start by fostering the development of supranational principles of contractual fairness to govern international commercial transactions.

\section{The Effect of Economic Integration on Environmental Standards}

$$
\text { By Joel R. Paul* }
$$

Today, we witness the steady growth of free trade areas and customs unions as one of the central characteristics of the new international economic order in Western Europe and the Americas. One of the principal concerns of regional economic integration has been its effect on domestic economic regulation-in particular, on environmental protection. The current debate over the ratification

\footnotetext{
${ }^{42}$ See H. Jessurun d'Oliveira, Towards a "European" Private International Law?, in B. DE WITTE \& Caroline forder (Eds.), The Common law of Europe and the Future of Legal Education 265, 266-67 (1991) (noting the "[g]rowing bulk of Community and para-Community conflict provisions" and that "the necessity to deal with rules from international sources" means that modern PIL codifications "have become interstitional, filling up the spaces which conventions have left open").

${ }^{43}$ See Jessurun d'Oliveira, supra note 42, at 276.

${ }^{44}$ See Gennady M. Danilenko, International Jus Cogens: Issues of Law-Making, 2 EUR. J. INT'L L. 42 (1991).

${ }^{45}$ See Tebbens, supra note 21 , at 68 (arguing that the "principles of proportionality and of nondiscrimination" may "reduce the freedom of the Member States to invoke their public policy," citing as an example the German rule restricting recovery in tort against German nationals to the extent allowed by German law, even if foreign law governs the tort).

${ }^{46}$ Tebbens, supra note 21, at 69 (discussing Article 16 of the Rome Convention and inquiring into the extent to which "Member States may declare their own rules, e.g., consumer protection, to be mandatory for the purpose of applying the Rome Convention in areas such as supply of financial services where EC directives allow foreign service suppliers to deal on terms fixed by the law of their own State").

${ }^{47}$ Jessurun d'Oliveira, supra note 42 , at 276.

${ }^{48} I d$. at 277 (citing examples from EC case law and legislation).

* Washington College of Law, The American University.
} 